\title{
Bancassurance Business Strategy in Life Insurance: a Case Study One of Joint Venture Company in Indonesia
}

\author{
Ikhwan Abiyyu ${ }^{1}{ }^{1}$, Mukhamad Najib $^{2}$, Alla Asmara ${ }^{3}$ \\ School of Business, Institute Pertanian Bogor University, Bogor, Indonesia ${ }^{1}$ \\ Faculty of Economics and Management, Institute Pertanian Bogor University, Bogor, Indonesia ${ }^{2}$ \\ Faculty of Economics and Management, Institute Pertanian Bogor University, Bogor, Indonesia ${ }^{3}$
}

\begin{tabular}{l} 
Info Article \\
History Article: \\
Submitted 14 November 2019 \\
Revised 3 February 2020 \\
Accepted 17 February 2020 \\
\hline Keywords: \\
Bancassurance; Life Insurance; \\
Business Model Canvas; SWOT; \\
Blue Ocean Strategy.
\end{tabular}

History Articl

Submitted 14 November 2019

Revised 3 February 2020

Accepted 17 February 2020

Bancassurance; Life Insurance;

Blue Ocean Strategy.

\begin{abstract}
This research will conduct bancassurance business strategy for one of life insurance company. Bancassurance business in Indonesia is wide open and needed the right strategy for every company. Life insurance companies in the bancassurance business hold an important roles as a party that providing the product for bank customers. The mapping is carried out for the current business conditions run by the company using BMC tool and will be deepened with a SWOT analysis for each component in BMC. To present a new market, the company need to apply a new strategy that has never been carried out by competitors, with the perspective of BOS, a write off-reduce-increase-create scheme will be implemented to produce $\mathrm{BMC}$ alternatives. The result showed three strategic issues for the company, there are product development by collaborating with general incurance, customer segmentation development especially for High Net Worth customers also offering product with foreign currency, and digital competency strengthening in selling and internal process. These three strategies can be used as extra ammunition for the life insurance companies to compete in the bancassurance business.
\end{abstract}

\section{Strategi Bisnis Bancassurance pada Asuransi Jiwa: Studi Kasus Salah Satu Perusahaan Patungan di Indonesia}

\begin{abstract}
Abstrak
Tujuan penelitian ini adalah menyusun strategi bisnis bancassurance untuk salah satu perusahaan asuransi jiwa. Bisnis Bancassurance di Indonesia terbuka lebar dan membutuhkan strategi yang tepat untuk setiap perusahaan. Perusahaan asuransi jiwa dalam bisnis bancassurance memegang pernana penting sebagai pihak yang menyediakan produk asuransi bagi nasabah bank. Pemetaan dilakukan dengan mengidentifikasi kondisi bisnis saat ini yang dijalankan oleh perusahaan menggunakan alat BMC dan akan diperdalam dengan analisis SWOT untuk setiap komponen dalam $B M C$. Untuk menghadirkan pasar baru, perusahaan perlu menerapkan strategi baru yang belum pernah dilakukan oleh pesaing, yaitu dengan perspektif BOS, skema menghapuskan-mengurangkanmeningkatkan-menciptakan akan diterapkan untuk menghasilkan alternatif BMC. Hasil penelitian menunjukkan tiga masalah strategis bagi perusahaan, yaitu pengembangan produk dengan menggandeng asurasni umum, pengembangan segmentasi pelanggan High Net Worth disertai dengan penyediaan produk mata uang asing, dan penguatan kompetensi digital baik dari sisi penjualan maupun proses internal. Ketiga strategi tersebut dapat dijadikan sebagai ekstra amunisi bagi perusahaan asuransi jiwa dalam bersaing di bisnis bancassurance.
\end{abstract}

JEL Classification: G22, L1

How to Cite: Abiyyu, I., Najib, M., Asmara, A. (2020). Bancassurance Business Strategy in Life Insurance: a Case Study One of Joint Venture Company in Indonesia. Jurnal Dinamika Manajemen, 11(1), 103-115. 


\section{INTRODUCTION}

The insurance business in Indonesia, especially for life insurance, recorded an excellent development, one of the factors was the increased public awareness of the importance of having a life insurance policy as protection from the risks of financial losses that could have occurred. Life insurance is a contract between the policyholder and the insurer, where the insurer agrees to pay the designated beneficiary an amount of money if certain events or risks occur. The risks in question include the risk of death, critical illness, or benefits due depending on the agreed insurance contract (Birritu, 2011). Life insurance is considered to be a long-term relationship between a consumer as a policyholder and a company as an insurer, should there any factors that important for a vibrant and growing life insurance market (Kjosevski, 2012). The essential function of life insurance is to provide financial protection to individuals and families.

Based on the report of the Asosiasi Asuransi Jiwa Indonesia (AAJI) which is Indonesian Life Insurance Association, that the life insurance business through Annualized Premium Equivalent for new businesses (APE new business) is the income received by the insurance company from the annualized premium, in 2014 (Rp26.3 trillion) until 2017 (Rp34.9 trillion) experienced a positive trend, but declined in 2018 (Rp33.4 trillion) due to the sluggish investment market especially in Indonesia. There are 61 life insurance companies in Indonesia, both national private companies and joint ventures that compete in this valuable business. Life insurance provides individuals and the economy as a whole with several important financial services. It is an instrument to manage income risk by providing coverage against income loss from death, as well as an investment vehicle for long-term savings (Savvides, 2006).

Distribution channels in the life insurance industry included agencies, cooperation with banks (bancassurance), Direct Marketing Tele Marketing (DMTM), employee benefits, insurance brokers, microinsurance and e-commerce insurance. Agency, bancassurance and DMTM distribution channels are the most significant contributors to life insurance companies for APE new business. The agency distribution channel is the distribution channel that dominated the contribution of APE new business from 2014 (48.2\%) to 2016 (39.3\%). Then in 2017, the bancassurance distribution channel began to shift the portfolio mix from the agency, with a percentage of APE new business contributions of $40.8 \%$ and $39.5 \%$ in 2018 . This shows that the bancassurance business is promising and has business potential for life insurance companies, as well as being a challenge for companies in competing in the life insurance industry in Indonesia. That is why this research explains more about the bancassurance business that runs in Indonesia and the potential business strategies that can be developed.

Csaba (2015) conducted a study related to the influential factors in the bancassurance business by using Ordinary Least Squares and Generalized Method of Moments to conclude that in the bancassurance business it is imperative to improve innovative products and meet consumer needs. Yulianto (2010) in his research explained that the selection of AXA Life as a partner to develop bancassurance in Bank Mandiri was appropriate, carried out by evaluating the factors that influence the selection of cooperation partners namely Compatibility, Capability \& Commitment. Pintér (2013) suggested that the concept of strategy and marketing of the bancassurance business in Hungary is to cross-sell and determine the level of integration from the institutional aspect. Chen (2015) explained that the maximum involvement of the Bank can improve the efficiency of the bancassurance business. The novelty of this study is to provide a new strategy idea that has never been applied before by the life insurance companies in bancassurance business competition in Indonesia.

\section{Bancassurance}

Based on the Financial Services Authority Regulation in Indonesia called OJK with regu- 
Ikhwan Abiyyu et al./ Bancassurance Business Strategy in Life Insurance ...

lation No.23/POJK.05/2015 about "Insurance Products and Insurance Product Marketing”, bancassurance business is a collaborative activity between a company and a bank to market insurance products through banks. Bancassurance activities in OJK Circular Letter Number 33 / SEOJK.03/2016 about "Application of Risk Management in Banks Conducting Marketing Cooperation Activities with Insurance Companies called Bancassurance" is classified in three business models, namely reference, distribution and work cooperation same product integration.

The provision of bancassurance in life insurance services by banks, is an established and growing channel for insurance distribution, though its penetration varies across different markets (Gupta \& Jain, 2011). Bancassurance is a sales channel through which insurance companies sell their portfolio of products using the bank's network. It is assumed that the bancassurance channel is a win-win situation for each and every stakeholder (Sengupta et al., 2015). Bank earns a fee amount from the insurance company apart from the interest income or it could be a profit-sharing. On the other hand, the insurance company increases its market reach and customers. The bank acts as an intermediary, helping the insurance firm reach its target customer to increase its market share (Marlien et al., 2017; Kumar, 2017).

The bancassurance business is a long-standing dream of offering a seamless service of banking, life \& non-life products, considering it as a channel for insurance company and also bank partner gives the insurance an unlimited exposure to the customers (Rajput, 2013). From the Bank side, Bancassurance has positive impact as bank strategy to venturing into other areas of business and diversification (Kamunya \& Omagawa, 2017). Both of Bank and Insurance Company there is a great opportunity to learn and to make improvements in bancassurance business (Rinoj, 2016).

\section{Business Model Canvas}

The business model explains the background of how an organization creates, commu- nicates and obtains values from a business. The concept of a business model must be understood by all parties involved with a presentation that is simple, relevant and intuitively easy to understand with no intention of simplifying the functions of a very complex company. Osterwalder and Pigneur (2015) divided several stages in compiling a business model into nine components consisting: Customer Segments (CS), Value Proposition (VP), Channels $(\mathrm{CH})$, Customer Relationships (CR), Revenue Streams (RS), Key Resources (KR), Key Activations (KA), Key Partners (KP) and Cost Structure (CS).

BMC can help companies innovate by providing a clear view of what companies need to achieve and focus on the most important strategic components and will have the greatest impact on business (Amanulla et al., 2015). BMC is a very good tool for the company to make planning and building new solutions, as well as improving the existing business. The model also identifies areas of innovation for business. Its application value means that it can be used in the preparation of a business plan in terms of the necessary information, content, contained analyses related to a marketing, operational, financial or organizational and management plan (Tokarski et al., 2017). BMC consists of nine basic components of a business model, instead of simply having them in a row, they are put on a canvas so the visualization of the different issues' relation is improved that helps the user to map, discuss, design and invent new business models (Ching \& Fauvel, 2013).

\section{SWOT Analysis}

Strengths, Weaknesses, Opportunities, and Threats (SWOT) is used to assess the strengths and weaknesses of the company's resources, and opportunities from the external side and the challenges faced. All organizations have strengths and weaknesses in the functional area of business, and no company is as strong or weak in all business areas (David, 2009; Ostewalder \& Pigneur, 2015). The function of a SWOT Analysis is to obtain information from 
situation analysis and separate it from internal and external issues (Ferrel \& Harline, 2005). SWOT-analysis helps the company achieve its goals or indicates that there are obstacles that must be faced or minimized Rangkuti (2013). The SWOT strategy formulation is carried out through a SWOT matrix resulting in four alternative strategies including SO (utilizing all the strengths possessed to seize opportunities), ST (using the strengths owned to overcome threats), WO (utilizing existing opportunities by minimizing the weaknesses owned) and WT (minimize weaknesses by avoiding threats).

\section{Blue Ocean Strategy (BOS)}

BOS is one strategy that can create new market space without having to become a follower of other companies (Kim \& Mauborgne, 2005). BOS can be used as a strategy tool used in the creation of new BMCs. The main principle used in BOS is to stay away from the competition by reconstructing market boundaries so that new market opportunities are created. By changing company strategic planning and using a systematic approach, the BOS showed how companies could reach beyond existing demand to find a new market space with the potential for huge profits and growth (Pitta, 2009). The BSC can align the company with internal resources and processes to effectively determine the ability of the company to pursue a blue ocean, as well as effectively be used to evaluate its implementation (Becker, 2010).

\section{METHOD}

This research is a concern to evaluate and propose a new strategy for one of the life insurance company in Indonesia. This company is a joint venture company and also one of the top 15 bancassurance business players in Indonesia. The portfolio mix of the business run by this company for each distribution channel, the bancassurance business is still number two compared to the agency distribution channel. Summary of data analysis methods used can be seen in Table 1. Meanwhile, in the past five years this company already has nine bank partners,

Table 1. Data Analysis Method Used

\begin{tabular}{|c|c|c|c|c|}
\hline Research Purposes & $\begin{array}{l}\text { Types \& Methods } \\
\text { of Data Retrieval }\end{array}$ & Data & Data Analysis & Output \\
\hline $\begin{array}{l}\text { Mapping company's } \\
\text { bancassurance busi- } \\
\text { ness into the BMC . }\end{array}$ & $\begin{array}{l}\text { Primary data: } \\
\text { Conducting in- } \\
\text { depth inter-views, } \\
\text { FGD, and observa- } \\
\text { tions. }\end{array}$ & $\begin{array}{l}\text { Nine BMC } \\
\text { components for } \\
\text { the company's } \\
\text { bancassurance } \\
\text { business. }\end{array}$ & $\begin{array}{l}\text { Descriptive } \\
\text { component of } \\
\text { BMC. }\end{array}$ & $\begin{array}{l}\text { Mapping com- } \\
\text { pany's bancas- } \\
\text { surance business } \\
\text { on BMC canvas. }\end{array}$ \\
\hline $\begin{array}{l}\text { Analyzing the SWOT } \\
\text { of company's bancas- } \\
\text { surance business for } \\
\text { each component in } \\
\text { BMC. }\end{array}$ & $\begin{array}{l}\text { Primary data: } \\
\text { In-depth inter- } \\
\text { views, FGD, and } \\
\text { observations } \\
\text { Secondary data: } \\
\text { Literature Study. }\end{array}$ & $\begin{array}{l}\text { Internal and ex- } \\
\text { ternal data from } \\
\text { the company. }\end{array}$ & $\begin{array}{l}\text { Combining } \\
\text { BMC and } \\
\text { SWOT. }\end{array}$ & $\begin{array}{l}\text { Strategic fac- } \\
\text { tors that are } \\
\text { strengths, } \\
\text { weaknesses, } \\
\text { opportunities, } \\
\text { and threats in } 9 \\
\text { components of } \\
\text { BMC. }\end{array}$ \\
\hline $\begin{array}{l}\text { Formulate the } \\
\text { alternative business } \\
\text { strategies for com- } \\
\text { pany's bancassurance } \\
\text { business. }\end{array}$ & $\begin{array}{l}\text { Primary data: } \\
\text { processing from the } \\
\text { 2nd point. }\end{array}$ & $\begin{array}{l}\text { Data from } 2 \text { nd } \\
\text { point results. }\end{array}$ & $\begin{array}{l}\text { Combining data } \\
\text { \& information } \\
\text { from SWOT } \\
\text { and BOS. }\end{array}$ & $\begin{array}{l}\text { New BMC as } \\
\text { an alternative to } \\
\text { the company's } \\
\text { bancassurance } \\
\text { business strat- } \\
\text { egy. }\end{array}$ \\
\hline
\end{tabular}


Ikhwan Abiyyu et al./ Bancassurance Business Strategy in Life Insurance ...

but only succeeded in taking a market share of $2.6 \%$. This should be a concern for the company, and it turns out that having many bank partners does not merely make the company a big player in the bancassurance business. This research aims to look at the company's current strategies and the end should ultimately provide alternative strategies that provide added value to the company's business, especially for bancassurance business.

The types and sources of data used consist of primary data, obtained directly through in-depth interviews and focus group discussions (FGD) with some expertise at the company, namely the Chief Executive Officer (CEO) and several group heads including Partnership Distribution, Marketing \& Communication, Actuary \& Product Development, and Investment. Secondary data, obtained in the form of reports from Asosiasi Asuransi Jiwa Indonesia (AAJI), Insurance Statistics Book, company annual reports and internal data, also the Government Regulations as well as some scientific publications such as articles, journals, and books as supporting data.

\section{RESULT AND DISCUSSION}

\section{Mapping Company's Bancassurance Busi- ness on BMC Canvas}

Currently, the company has cooperation with several banks, both state-owned banks, national private banks and joint venture banks, and has market segmentation from mass to affluent. Looking at the age distribution, it is dominated by customers aged 46 to 55 years who are of productive age and need life protection. In 2014, the company has cooperated with several banks and offered insurance products, namely unit-linked premiums and credit life insurance. Unit link with premium is also an insurance product that is included with investment, while credit life insurance is a product with life insurance if there is a risk to customers who have loans at the bank. Mid-2015, they selling unit-linked products with periodic premiums that have more complete insurance benefits and more complex features. Then, in 2019 the company starting to provide a new product, namely group protection that covers protection for several insured in one organization.

Channels owned by the company in the bancassurance business consist of offline channels in the form of marketers called Bancassurance Specialists and online including websites, e-mail, social media, and telephones. This company has a strategy to build relationships with its customers through programs such as DNA Journal health facilities, iClick digital applications, and iServices. The revenue streams obtained by the company consist of new business premiums and advanced premiums and investment returns made by the company. Active resources are a team in the Partnership Distribution division that is headed by a Chief of Partnership Distribution.

Furthermore, there are several teams, including Strategic \& Business Development, Bancassurance Sales, Training \& Module Development, and Support. The main activity of bancassurance is marketing insurance products to bank customers. According to the Circular of OJK Number 32/SEJOK.05/2016 about "Marketing Channels of Insurance Products Through Cooperation with Banks (Bancassurance)", there are three business models, namely reference, distribution cooperation, and product integration. The main partnership of this company for the last five years consists of several banks that have contributed to APE's new business which is greater than other banks, including Bank BTN, Bank DBS, Bank ANZ, Bank OCBC NISP, and Bank BTPN. Besides, for other banks complement the company's business strategy and become a low priority.

Meanwhile, for the structure of costs incurred by the company, consisting of costs for external activities (commissions for banks and marketing costs) as well as costs for company operational activities such as employee salary, facilities and infrastructure and improving 
the quality of resources owned. After the nine components of the bancassurance business from the company already explained, the next step is to map them to a picture of what is commonly referred to as "canvas". Mapping the elements in each component will make it easier to summarize the overall picture of business activities that are currently running. Please refer to Figure 1. is an exclusivity of bancassurance cooperation conducted by several insurance companies with high potential banks. The $2 \mathrm{~ns}$ factor is marketing insurance products with guaranteed returns in a short time, so the company is unable to pay benefits on time. For needs and demands, the trend of people's purchasing power for life insurance products, especially in the bancassurance distribution channel, has increased in the

\begin{tabular}{|c|c|c|c|c|}
\hline 8. Key Partners & (28) 7. Key Activities & 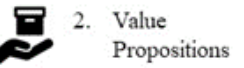 & $\begin{array}{ll}\text { 4. } & \text { Customer } \\
& \text { Relationships }\end{array}$ & 83 1. $\begin{array}{l}\text { Customer } \\
\text { Segments }\end{array}$ \\
\hline BTN & References & \multirow{2}{*}{$\begin{array}{l}\text { Credit Life Insurance } \\
\text { Product }\end{array}$} & Health facility called & Market segmentation \\
\hline Bank DBS & Distribution Cooperation & & 1Signature (DNA Journal) & \\
\hline Bank ANZ & Product Integration & \multirow{2}{*}{$\begin{array}{l}\text { Life Insurance Product } \\
\text { with Investment Benefit } \\
\text { (Unit Link) }\end{array}$} & $\begin{array}{l}\text { Investment facility called } \\
\text { ROBO ARMS }\end{array}$ & \multirow[t]{8}{*}{$\begin{array}{l}\text { Dominated by customers } \\
\text { age } 46 \text { to } 55 \text { years old }\end{array}$} \\
\hline Bank OCBC NISP & & & Digital application called & \\
\hline \multirow[t]{6}{*}{ BTPN } & & Group Life Product & iClick and iServices & \\
\hline & $\oint_{0}$ 6. Key Resources & & 2ిం 3. Channels & \\
\hline & Strategic \& Business Dev. & & Bancassurance Specialist & \\
\hline & Bancassurance Sales & & E-mail & \\
\hline & Training \& Module Dev. & & Website \& Social Media & \\
\hline & Support Team & & Telelphone & \\
\hline$\$$ 9. Cost Structure & & & 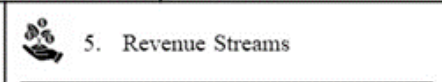 & \\
\hline Bank Commission & & & \multirow{2}{*}{$\begin{array}{l}\text { Regular Premium \& Single Premium } \\
\text { (new business \& renewal premium) }\end{array}$} & \\
\hline Sales Commission & & & & \\
\hline Operational Costs & & & Investment Results & \\
\hline
\end{tabular}

Figure 1. BMC Mapping for Company's Bancassurance Business

\section{Business Environment Analysis}

It takes consideration of customer needs, advances in renewable technology, and obstacles that arise in the modeling of bancassurance business. Analysis of the business environment is carried out by mapping key areas, such as market analysis, industry strength, and critical trends, aimed at developing new business models.

\section{Market Analysis}

Market Analysis conducted to understand the opportunities and threats faced by the company. Several factors that can affect the bancassurance business component include market issues and needs and demands. The 1 st factor last five years. Also, the benefits of the bancassurance distribution channel are not only felt by insurance companies and banks but also the customers themselves, because customers are given the convenience of starting to make product purchase transactions, process premium payments to the process of filing insurance benefit claims.

\section{Industry Strength}

Industry strength can be seen from competitors, new players, and other businesses. There are five leading competitors in the spotlight of this company, including AXA Mandiri, AIA, and Allianz, which are joint ventures and local companies, namely Simas Jiwa and Jiwasraya, 
please refer to Figure 2 to see the comparison based on APE new business.

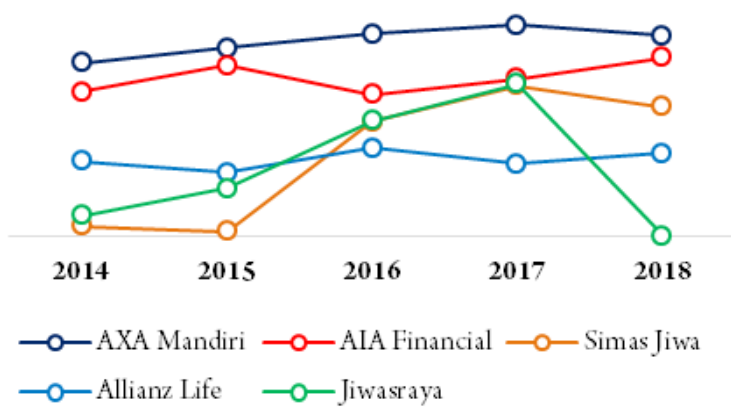

Figure 2. The Growth of APE New Business from Bancassurance Business versus Leading Competitors

Source: AAJI 2014-2018

Meanwhile, for new players in competitive bancassurance businesses, including Astra Aviva Life, Capital Life, and BRI Life have defeated the company's achievements and captured market share in 2018, please refer to Figure 3 to see the comparison based on APE new business.

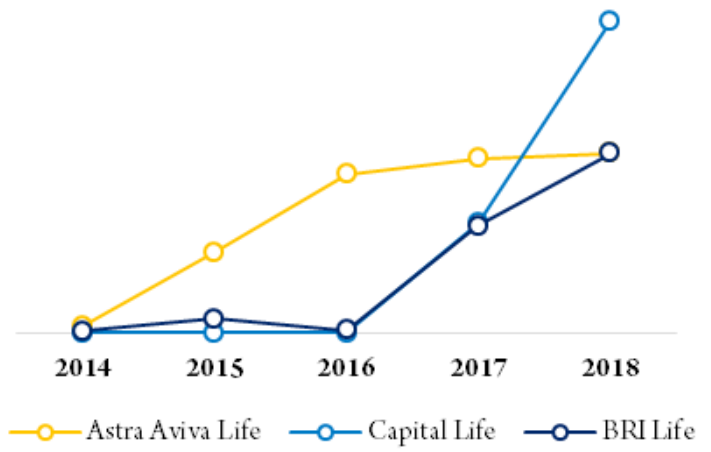

Figure 3. The Growth of APE New Business from Bancassurance Business versus New Competitors

Source: AAJI 2014-2018

Not only life insurance companies that provide insurance products in Indonesia, but they're also are competitors who are not insurance companies such as digital companies and financial technologies. These other busines- ses can be categorized as insurance businesses through digital platforms, including GoBear Indonesia, PasarPolis.com and JAGADIRI. With the development of the insurance business through digital platforms in the insurance industry, it will be a threat to insurance companies, especially life insurance companies that are still operating traditionally, because people can quickly and easily access insurance products without having to meet with marketers or sales directly.

\section{Critical Trends}

Critical Trends are necessary to analyze to support changes in the company's bancassurance business model for the better. This critical trend analysis can review and look forward to how technology trends, trends from regulation, and community trends. In building a business model, it is necessary to discuss the changes in the environment and analyze the direction in which the changes occurred. It is intended that the new business model produced can be used as a means or consideration adapt to changes.

\section{SWOT Analysis in BMC Components and Strategy Formulation at BMC}

SWOT identification is an amalgamation of information that has been obtained from an internal analysis of nine BMC components and environmental model business analysis. SWOT identification will explain the weaknesses, strengths, opportunities, and threats faced by the company in each component of BMC. After identifying the SWOT, the next step is to conduct a SWOT analysis to obtain alternative strategies by first selecting the strategic issues that exist in the results of the SWOT identification. The explanation of strategic issues is presented in the SWOT analysis matrix in Table 2.

\section{The Explanations for Each Strategic Issues:}

Development of a business model with a general insurance company (Strategy SO 1)

With the availability of the Strategic \& Business Development team and diverse busi- 
Table 2. SWOT Analysis Matrix for Company's Bancassurance Business

\begin{tabular}{|c|c|c|}
\hline & Strengths (S) & Weaknesses (W) \\
\hline & $\begin{array}{l}\text { Auto Risk Management Sys- } \\
\text { tem (ARMS) feature in unit- } \\
\text { link products (VP). } \\
\text { The Strategic \& Business De- } \\
\text { velopment team exists (KR). } \\
\text { Reference business models, } \\
\text { product distribution and inte- } \\
\text { gration cooperation (KA). }\end{array}$ & $\begin{array}{l}\text { Not yet focused on HNW } \\
\text { (CR). } \\
\text { Current products are not } \\
\text { unique and follow competitors } \\
\text { (VP). } \\
\text { Limited salesperson and not } \\
\text { yet competent (KR). } \\
\text { Back office capacity limitation } \\
\text { (KR). } \\
\text { Agreement with banks does } \\
\text { not long last }(\mathrm{KP}) \text {. }\end{array}$ \\
\hline Opportunities (O) & SO Strategy & WO Strategy \\
\hline $\begin{array}{l}\text { Potential HNW market (CS). } \\
\text { Products in foreign currencies (VP). } \\
\text { Collaboration with general insurance } \\
\text { (KA). } \\
\text { Potential non-bank business entities } \\
\text { or financial institutions (KP). } \\
\text { Invest in foreign currency US Dollar } \\
\text { (RS). }\end{array}$ & $\begin{array}{l}\text { Development of a business } \\
\text { model with a general insurance } \\
\text { company }(\mathrm{S} 2, \mathrm{~S} 3, \mathrm{O} 3, \mathrm{O} 4) \text {. } \\
\text { Development of investment } \\
\text { strategies }(\mathrm{S} 1, \mathrm{O} 2, \mathrm{O} 5) .\end{array}$ & $\begin{array}{l}\text { Development for HNW mar- } \\
\text { ket segmentation (W1, W2, } \\
\text { O1, O2). } \\
\text { Product development with for- } \\
\text { eign currencies (W2, O2, O5). }\end{array}$ \\
\hline Threats $(T)$ & ST Strategy & WT Strategy \\
\hline $\begin{array}{l}\text { Digitalization by competitors (KA). } \\
\text { Employee turns over (KR). } \\
\text { Termination of agreement with } \\
\text { banks (KP). } \\
\text { Un-efficient operation cost }(\mathrm{C} \$) \text {. } \\
\text { Lose in the digital application }(\mathrm{CH}) \text {. }\end{array}$ & $\begin{array}{l}\text { Business planning with digital- } \\
\text { based competencies (S2, T1, } \\
\text { T4, T5). }\end{array}$ & $\begin{array}{l}\text { Continuing agreement with } \\
\text { existing bank partners and the } \\
\text { binding new agreement with } \\
\text { potential bank partners (W5, } \\
\text { T3). } \\
\text { Development of employee } \\
\text { competencies (W3, W4, T2, } \\
\text { T4). }\end{array}$ \\
\hline
\end{tabular}

ness models, the company can expand its bancassurance business by working with general insurance companies. The business model is done by bundling life insurance and general insurance products. This business model can be implemented not only by cooperating with banks, but also with other potential markets, namely non-bank business entities or other financial institutions. The non-bank business entity in question is the Rural Credit Bank, while the other financial institutions in question are cooperatives and business capital lending institutions.

\section{Development of Investments Strategies (Strategy SO 2)}

The company with the ARMS mainstay feature, is a competency that is not yet possessed by other life insurance companies in Indonesia. With this feature, a company can develop a company's investment performance to match its desires and minimize fluctuating investment risks. This feature is equipped with investment parameters according to the customer's risk profile. The development of an investment strategy is essential because it can be a level of customer satisfaction for in- 
Ikhwan Abiyyu et al./ Bancassurance Business Strategy in Life Insurance ...

surance products that have investment benefits. Besides, the development of this strategy can increase the company's revenue in managing investment funds. The development of an investment strategy can be in the form of placement of investment funds in investment instruments that have never been placed before, or even investment instruments that have the potential to develop.

\section{Development for HNW Market Segmentati- on (Strategy WO 1)}

The unavailability of products and services dedicated to the HNW is a challenge for the company as well as the potential market. The products offered will undoubtedly be different from the products marketed for mass segmentation to the middle class, so that it becomes more valuable for HNW customers in having insurance products. Also, products with foreign currencies, especially US\$, are superior products that can be used as the main products for HNW segmentation, given that many have overseas assets and transactions conducted in US\$ currency.

\section{Product Development with Foreign Curren- cies (Strategy WO 2)}

The insurance products currently owned by this company in the bancassurance business are only available in Rupiah. There is a need to develop more competitive products in foreign currencies, especially US\$. Insurance products with US\$ currency can be more competitive products and complement the insurance product portfolio for customers.

\section{Business Planning with Digital-based Com- petencies (Strategy ST) \\ Company competence in presenting di-} gital-based insurance products is a new strategy and is an innovation from the company that must be done. Considering competitors who have begun to enter are digitizing life insurance products. This strategy can be used as a starting point for companies to move from conventional businesses to digital-based businesses, starting from the product sales process, operations to after-sales activities that can be carried out independently by customers. This strategy will undoubtedly have an impact on corporate investment in the development of digital competencies, and empowered resources should have sufficient capacity to build a digital environment.

\section{Continuing Agreement with Existing Bank Partners and a Binding New Agreement with Potential Bank Partners (Strategy WT 1)}

This strategy has two objectives, namely how companies maintain business ties with existing partner banks and how companies look for new businesses from banks that have not been partners. Given the open competition in life insurance in Indonesia, it is crucial for this company must convince banks to have bancassurance cooperation with companies. The company realizes that large banks that already have cooperation with other insurance companies have little opportunity to do cooperate, where the company also has obstacles in terms of capital or initial capital to establish cooperation with banks that have tremendous market potential.

\section{Development of Employee Competencies (Strategy WT 2)}

This strategy is more about how companies manage employees, both back-office employees and marketers who market products directly - coupled with the limited number of marketers and high turnover of potential employees. Competence development is felt to be very necessary, both through training supplies that can train employees' soft skills as well as clear career opportunities and compensation following with employee performance.

\section{Application of the SWOT Strategy into the BMC Component}

The seven strategies outlined above will be a reference in the next step, namely combining these strategies with the Blue Ocean Strategy. However, before this, the mapping of BMC 
components affected by the seven strategies was needed, both direct with black column and indirect with the grey column that can be seen in Table 3. has changed with the development of strategies for the HNW segment. Starting from providing products specifically for the HNW segment as well as services related to customer relations

Table 3. SWOT Strategy in Mapping the New BMC

\begin{tabular}{|c|c|c|c|c|c|c|c|c|c|}
\hline \multirow{2}{*}{ SWOT Strategies } & \multicolumn{9}{|c|}{ BMC Components } \\
\hline & CS & VP & $\mathbf{C H}$ & CR & RS & $\mathbf{K R}$ & KA & $\mathbf{K P}$ & C\$ \\
\hline \multicolumn{10}{|l|}{$\begin{array}{l}\text { SO1 = Development of a business model } \\
\text { with a general insurance company. }\end{array}$} \\
\hline \multicolumn{10}{|l|}{$\begin{array}{l}\mathrm{SO} 2=\text { Development of investments strat- } \\
\text { egies. }\end{array}$} \\
\hline \multicolumn{10}{|l|}{$\begin{array}{l}\text { WO1 = Development for HNW market } \\
\text { segmentation. }\end{array}$} \\
\hline \multicolumn{10}{|l|}{$\begin{array}{l}\text { WO2 = Product development with for- } \\
\text { eign currencies. }\end{array}$} \\
\hline \multicolumn{10}{|l|}{$\begin{array}{l}\text { ST = Business planning with digital-based } \\
\text { competencies. }\end{array}$} \\
\hline \multicolumn{10}{|l|}{$\begin{array}{l}\text { WT1 = Continuing agreement with exist- } \\
\text { ing bank partners \& a binding new agree- } \\
\text { ment with potential bank partners. }\end{array}$} \\
\hline $\begin{array}{l}\text { WT2 = Development of employee com- } \\
\text { petencies. }\end{array}$ & & & & & & & & & \\
\hline
\end{tabular}

The strategies resulting from the SWOT analysis can influence each other in several components in the new BMC that will be created. Changes that occur can be directly or indirectly. Direct changes are changes that occur in the BMC component due to the implementation of the SWOT results strategy, while indirect changes are changes that occur in other components due to major changes in the BMC component due to the implementation of the SWOT strategy.

\section{New BMC as an Alternative for Bancassurance Business Strategy}

BMC improvement is the application of seven strategies resulting from the SWOT analysis. Where, the key strategies for BMC improvement include product development, customer segmentation development, and strengthening digital competencies. Improvement with the BOS perspective will result in which components are reduced, eliminated, enhanced, and created. The customer segment components. Whereas the mass to affluent segments will continue to be carried out, and the target age for customers will be widened from millennials to 20 years to 30 years. The development of investment strategies that will be carried out overseas exposure, so that it is expected to be an added value for the products offered to customers and is expected to become coffers for the company's income.

The overseas investment instrument of concern is Exchange-Traded Funds (ETF), which will be one of the innovations of the investment strategy for life insurance products. The marketing strategy that has not been carried out by life insurance companies in Indonesia is direct marketing by registering via a mobile application at a partner bank. This mobile application will be used via bank customers' smartphones, by first downloading the application. This strategy is classified in the creation of BOS which will reduce operational costs and efficiency in the number of marketers. The results of BMC improvement with the BOS perspective can be 
Ikhwan Abiyyu et al./ Bancassurance Business Strategy in Life Insurance ...

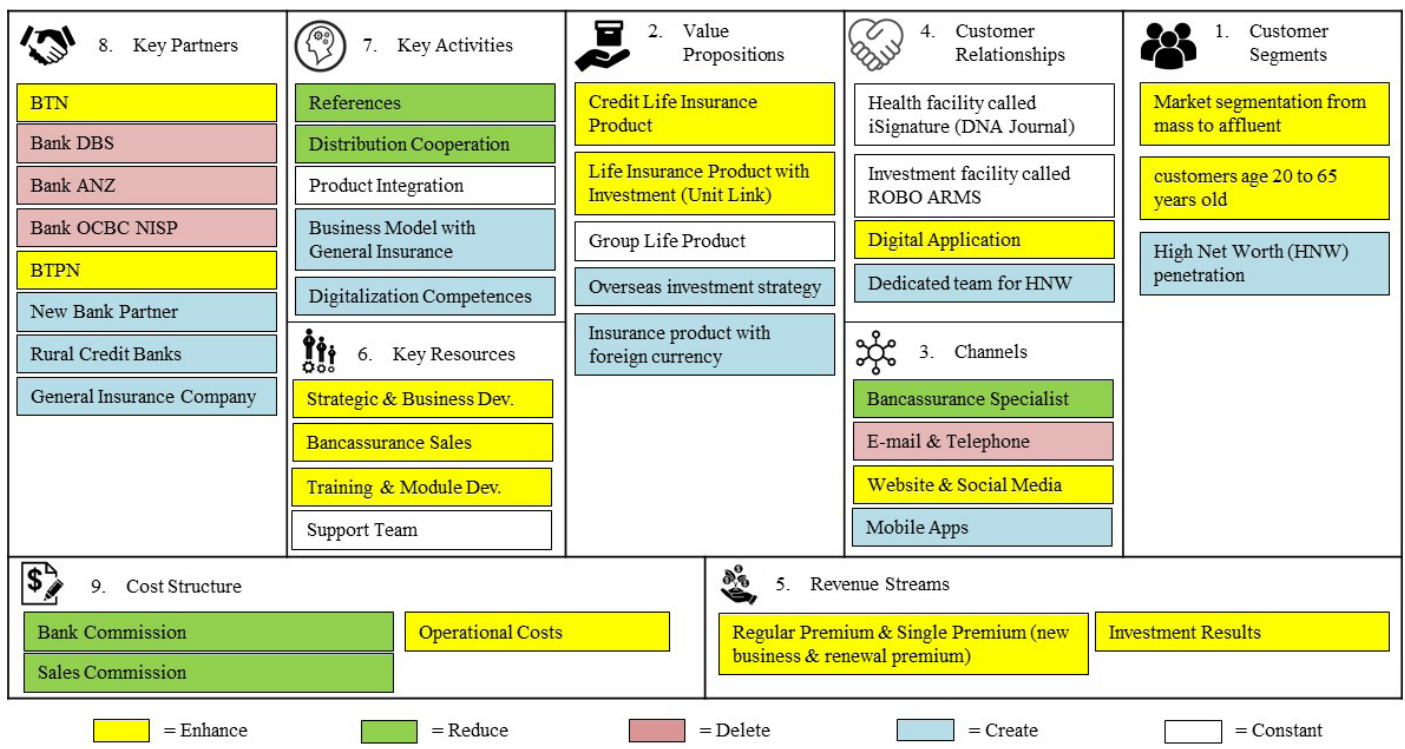

Figure 4. New BMC as An Alternative to Bancassurance Business Strategy

seen from Figure 4. The business model created is a combination of products or bundling of life insurance products with general insurance. For example, general insurance with motor vehicle insurance products, customers buy vehicles with installments accompanied by protection from losses incurred from risks such as loss and natural disasters. This strategy indirectly influences other components, namely main resources and key partners. The end of the cooperative relationship with several banks will have an impact on the alternative BMC produced, then the company will focus on partner banks that still have cooperation and develop the potential of Rural Credit Banks.

From the results of BMC improvements for the company's bancassurance business based on SWOT analysis and the implementation of four steps of the BOS perspective, three alternative strategies as the main idea that can be adopted for the company to compete in the bancassurance business in Indonesia. The intended alternative strategies include product development, customer segmentation development, and digital competency strengthening.

\section{CONCLUSION AND RECOMMENDATION}

The results of the mapping on the BMC bancassurance business of the company's cur- rent conditions that indicate there should be change or improvement with the new strategy. There are strategic issues in SWOT identification that have been carried out on nine BMC components of the bancassurance business that can be developed as a strategy informing alternative BMC strategies. New alternative BMC strategies that are refined with the direction of the BOS framework for business improvement in the future, including product development, customer segmentation development, and strengthening digital competencies. The first strategy is product development by collaborating on life insurance and general insurance products for bank customers. The second strategy is to focus on the HNW market segment by offering US \$ currency products as well as overseas investment strategies. Furthermore, the latter is a strategy to develop and strengthen digital competence by exploring the potential of product marketing business channels through mobile apps at banks and the sales process to after sales with competent digital services.

The advice given for this company is to improve the current business model immediately and correct the weaknesses and take advantage of the opportunities and strengths that exist. The new BMC results of this study can be used as a strategy for the company to apply in the future. 
Recommendations given for further research, are: (1) Expanding the scope of research which in this study is limited to one life insurance company. Researchers can then develop research using objects, namely life insurance companies that have large bancassurance businesses. (2) This research was conducted with the concept of BMC and SWOT analysis approach and complemented by the application of qualitative BOS. Future studies can complement the quantitative approach using data, be it data from company reports or data from questionnaire results submitted to customers or banks as the most important external parties in the bancassurance business.

\section{REFERENCES}

Asosiasi Asuransi Jiwa Indonesia. (2014-2018). Laporan Kinerja Kuartal IV Asosiasi Asuransi Jiwa Indonesia Tahun 2014 Sampai dengan Tahun 2018. Jakarta: Asosiasi Asuransi Jiwa Indonesia.

Amanulla, A. N., Faizah, A. A., Farah, N. H., \& Jamaludin, I. (2015). Comparison of Business Model Canvas (BMC) among the Three Consulting Companies. International Journal of Computer Science and Information Technology Research, 3(2), 462-471.

Becker, H. (2010). Using Blue Ocean Strategy in Performance Evaluation. International Journal of Strategic Management, 10(2), 140-147.

Birritu. (Ed.). (2011). The Launch of Credit Bureau Heralds the Beginning of a New Approach in Credit Processing, Extension and Management. National Bank of Ethiopia-Quarterly Magazine. Issued No 111.

Chen, Y. C. (2015). The Impact of Bancassurance on Efficiency and Profitability of Banks: Evidence from the Banking Industry in Taiwan. Thesis. National Chengchi University.

Ching, H. Y., \& Fauvel, C. (2013). Criticism, Variations, and Experiences with Business Model Canvas. European Journal of Agriculture and Forestry Research, 1(2), 26-37.

Csaba, S. J. (2005). Determinants of Bancassurance Demand and Life Insurance Consumption. Thesis. University of New South Wales.

David, F. R. (2009). Strategic Management Concepts and Cases 13th Edition. South California: Prentice Hall.
Ferrel, O. C., \& Harline, D. (2005). Marketing Strategy. South Western: Thomson Corporation.

Gupta, S. Jain, A., \& Anubha. (2011). Bancassurance-a New Feasible Strategy in Banking \& Insurance Sector Moving Fast in India. International Journal of Research in IT \& Management, 2(2), 771-781.

Kamunya, J., \& Omagwa, J. (2017). Bancassurance \& Profitability of Selected Commercial Banks in Kenya. The International Journal of Business \& Management, 5(11), 297-303.

Kim, W. C., \& Mauborgne, R. (2005). How to Create Uncontested Market Space and Make the Competition Irrelevant. Harvard Business Review, 4(13), 1-2.

Kjosevski, J. (2012). The Determinants of Life Insurance Demand in Central and Southeastern Europe. International Journal of Economics and Finance, 4(3), 237-247.

Kumar, R. (2017). Bancassurance: Emerging Prospects and Issues in India. International Journal of Academic Research and Development, 2(1), 33-36.

Marlien, R. A., Alimaskur, A., \& Setiawan, M. (2017). Salesperson Capability on CoCreation Value. Jurnal Dinamika Manajemen, 8(2), 143-151

Ostewalder, A., \& Pigneur, Y. (2015). Business Model Generation. Jakarta: PT Elex Media Komputindo.

Pintér, É. (2013). Strategic and Marketing Aspect of Bancassurance-Service Innovation in Hungary. Thesis. University of Pecs.

Pitta, D. (2009). Issues in a Down Economy: Blue Oceans and New Product Development. Journal of Product \& Brand Management, 18(4), 292-296.

Rajput, V. U. (2013). Research on Bancassurance. International Journal of Scientific and Research Publications, 3(7), 1-6.

Rangkuti F. (2013). Analisis SWOT Teknik Membedah Kasus Bisnis: Cara Perhitungan Bobot, Rating, dan OCAI. Jakarta: Gramedia Pustaka Utama.

Rinoj, P. K. (2016). Trends in Bancassurance and its Business Model. Indian Journal of Applied Research, 6(2), 630-632.

Sengupta, R., Kanti, S. M. \& Das, S. (2015). Emergence of Bancassurance in India-a Literature Review. International Journal in Management and Social Science, 3(8), 480490. 
Ikhwan Abiyyu et al./ Bancassurance Business Strategy in Life Insurance ...

Savvides, S. (2006). Inquiry into the Macroeconomic and Household Motives to Demand Life Insurance: Review and Empirical Evidence from Cyprus. Journal of Business and Society, 19(1), 37-79.

Tokarski, A., Tokarski, M., \& Wojcik, J. (2017). The Possibility of Using the Business Model
Canvas in the Establishment of an Operator's Business Plan. Torun Business Review, 16(4), 17-31.

Yulianto, T. (2007). Strategic Alliances dalam Upaya Peningkatan Usaha Bank: Studi Kasus Kerja Sama Bancassurance di Bank Mandiri. Thesis. Universitas Gadjah Mada. 